\title{
The Personal Values of Small-Business Entrepreneurs: Evidence from Brazil
}

\author{
Daniel Lima ${ }^{1}$ \\ lima.df23@gmail.com | (1) 0000-0001-8526-9401 \\ Edson Kubo ${ }^{1}$ \\ edson.kubo@prof.uscs.edu.br | (1) 0000-0001-9017-2487 \\ Eduardo Oliva ${ }^{1}$ \\ eduardo.oliva@prof.uscs.edu.br | (1) 0000-0002-7454-3759
}

\begin{abstract}
Despite the apparent relationship between personal values and entrepreneurship, this topic $t$ has been subject to little academic research. This article aims to explain, in the Brazilian context, how the personal values of entrepreneurs influence the degree of professionalism in their business. The article uses a descriptive and exploratory quantitative approach, with data collected via a survey and focus group. Results show that, in the Brazilian context, ethics and capitalist values have a greater influence on professionalism than do risk, innovation, family history, etc. Certain personal values of small-business entrepreneurs become organizational values that drive their actions in challenging environments. The finding that only one of the ten independent variables has been considered statistically influential on professionalism constitutes its main theoretical contribution. It rethinks professionalism, no longer as a dependent variable, but as a personal value, like the rest, in independent, innovative and sovereign way.
\end{abstract}

\section{KEYWORDS}

Personal Values, Small-Business Entrepreneurs, Professionalism 


\section{INTRODUCTION}

Around 1970, the first theories of values were already being delineated. Rokeach (1968), one of the pioneers in the field, defined values as beliefs that determine a specific model of social conduct. Later, the author added that values define attitudes and behaviors and, once they are internalized, become, conscious or unconsciously, a pattern or criterion to guide actions and moral judgment in relevant situations (Rokeach, 1981; Tornikoski and Maalaoui, 2019).

While this theme has typically been the subject of studies in the field of psychology, based on a hypothesis by Hofstede (1980) that personal values are linked to organizational culture and, therefore, influence administrative aspects, it has also begun to garner interest from management scholars. From 1990, Schwartz (1990, 1992, 1994), greatly inspired by Rockeach (1981), began to develop an inventory of personal values that incorporates universal and cultural values, and to delineate the system in which they are structured and interact with one another. The instrument provides quantifiable data about values that explain the behavior of a specific social group, and therefore comprises a clarifying tool (Campos \& Porto, 2010; Pasquali \& Alves, 2004; Sambiase, Teixeira, Bilsky, Araújo, \& Domenico, 2014; Tamayo \& Porto, 2009; Tinoco, Assêncio, João, \& Claro, 2011; Freire-Gibb \& Gregson, 2019).

In a related vein to that of Schwartz's (1990) research, Brazilian entrepreneurship has experienced growth due to the fact that the economic crisis led several companies to declare bankruptcy and thereby increased unemployment. This motivated entrepreneurs to act due their need to survive (Ferreira, Capra, Pereira, Abreu, \& Silveira, 2011; Wiklund, Wright, \& Zahra, 2019), and entrepreneurial initiatives became an alternative to the negative scenario of that time.

In periods of economic setback, the chances of getting a job are quite low, which pushes social minorities to choose self-employment-defined as a category of worker that builds their own enterprises alone, are their own boss and control their time and speed of work (Bulgacov, Cunha, Camargo, Meza, \& Bulgacov, 2011; Carrão, 2004; Castilho, 1995; Pamplona, 2001; Covin \& Wales, 2019; Freire-Gibb \& Gregson, 2019).

Entrepreneurs who are primarily motivated by need, despite having mastering specific techniques in their field, lack management training and planning, which constitutes a restriction for business development (GEM, 2013; Gerber, 1995; Roche, 2002, Wang, Walker, \& Redmond, 2011). In line with authors such as Gerber (1995), Roche (2002), Wang et al. (2011), and Oliveira, Silva, Araujo, and Gilson (2013), this article suggests that an entrepreneur's administrative capacity is linked with their business professionalism.

Vignochi, Lezana and Camilotti (2014) stated that understanding the influence of values on entrepreneurial action can support the creation of new tools to help enhance entrepreneurs' expertise. This article suggests that the field of entrepreneurship is permeated by the entrepreneurs' personal values. Despite this fact, this was the only study that jointly addresses values and entrepreneurship which was found in the database of the Scientific Periodicals Eletronic Library (SPELL). Searches conducted in May 2016 so far with the term "values" in the database of the main academic journals in the field of management in Brazil, such as the Revista de Administração Contemporânea (RAC), the Revista de Administração de Empresas (RAE) and the RAUSP Management Journal (RAUSP), all with A2 (i.e. Qualis Classification) obtained by the Coordination for the Improvement of Higher Education Personnel (CAPES) in Brazil, did not show any results linking values to the figure of the entrepreneur. Internationally, journals with an emphasis on entrepreneurship have been integrated into these searches, such as The Journal of Entrepreneurship, Journal of Small Business and Entrepreneurship, International Journal of Entrepreneurship and Small Business, Journal of Innovation and Entrepreneurship, Entrepreneurship: theory and practice, among 
others. It was observed that the scarcity of Brazilian research that specifically investigates the relation between the entrepreneur's personal values and the degree of business professionalism is representative of the same scarcity in the world academic scenario.

Therefore, in spite of the apparent relationship between values and entrepreneurship, the subject has been subject to little research to date. This raises the following research question: How do the personal values of entrepreneurs influence the degree of professionalism of their business? Besides this main research objective, it also aims to accomplish specific research objectives such as describing the inventory of personal values of the entrepreneur and relating the entrepreneur's personal values to aspects of business professionalism.

This article is divided in five main parts. After this introduction, a literature review is presented on values and entrepreneurship. This is followed by an outline of methods, a summary of the study's results, and conclusions, respectively.

\section{VALUES AND ENTREPRENEURSHIP}

Schwartz $(1994,2006)$, using a positivist paradigm, adopted the premise that values are motivational constructs that represent individuals' preexisting needs. Schwartz $(1994,2006)$ further stated that values, acquired via socialization, work as a pattern to judge and justify actions. Tamayo, Mendes and Paz (2000) defined values as principles related to models of desirable behavior that guide the actions of either the individual or a group. Therefore, values influence the lives of all people, and are an essential element to explain human behavior (Granjo \& Peixoto, 2013; Tornikoski \& Maalaoui, 2019).

In general, values are linked to the conception of what is desirable and impactful with respect to one's own behavior, and in judging the behavior of others. Values may be accepted as going beyond specific situations and to guide decisions, though the extent to which they do so varies according to each individual (Rokeach, 1973; Schwartz, Cieciuch, Vecchione, Davidov, Fischer, \& Konty, 2012; Granjo \& Peixoto, 2013; Tornikoski \& Maalaoui, 2019; Manning, Stokes, Tarba, $\&$ Rodgers, 2020). Silva and Fossá (2014) indicated that values constituted the inner pillars of actions, and help to rationalize conceptions that delineate preferences for certain courses of action over others.

Martens and Freitas (2008), Zuccari and Belluzzo (2016) and Williamson, Battisti, Leatherbee and Gish (2019) stated that entrepreneurial behavior is related to certain personal values, such as the need for independence, the ability to strategize, capitalist values, and risk and innovation propensity. Bruna Junior, Ensslin, Ensslin, Lezana, and Garcia (2010) and Vignochi et al. (2014) highlighted the important role of the combination of the entrepreneur's personal values and the business segment, stating that these must match and be consistent with one another. To invest time and money in a business, there must be an affinity between the entrepreneur's personal values and the kind of business. Once the first challenge of lack of money has been overcome, they invariably run into another problem: the lack of administrative knowledge to run their business, which is as important as understanding the specific technical procedures within their field.

Baron and Shane (2007) and Ching and Kitahara (2015) defined entrepreneurship simply as the process through which the entrepreneur acts. However, according to Armond and Nassif (2009), and Frese and Gielnik (2014), controversy among scholars over who the entrepreneur is and how they might be identified is intense, and the results are inconclusive, and often conflicting. With this difficulty in defining the entrepreneur profile, Carland, Boulton, and Carland (1984) and Mattingly (2015) suggested that there are several types of entrepreneurs, where the simplest 
being one who creates and then operates a small business (Gartner, 1989 Peredo \& Mclean, 2006; Sharma \& Chrisman, 1999; Verga \& Silva, 2014).

In this context, Carton, Hofer and Meeks (1998) stated emphatically that entrepreneurship does not occur without the creation of a company. However, Cooper and Dunkelberg (1996), Julien, Marchesnay e Machado (2010), Kuratko (2011), Anderson and Gaddefors (2016) refuted this, suggesting that entrepreneurship theory must transcend the simple creation of a company.

Carland et al. (1984), Kuratko (2011), and Covin and Wales (2019) used risk as a factor to distinguish entrepreneurs and managers. However, although Schumpeter (1934) recognized risk propensity as inherent to the entrepreneur, he realized that this is equally inherent to the small business manager, and suggested that the characteristic of innovation, connected with the product or service offered by the business, be adopted as main criterion to classify the entrepreneur. Also relevant is that the entrepreneur adopts strategic practices with the aim of increasing their profits (Carland et al., 1984; Mattingly, 2015). However, the small business owner does aim to make their company grow beyond what they are able to control, which is why many small companies remain small throughout their existence (Carland et al., 1984).

The wealth generated from entrepreneurship has changed the global scenario of shortage, which explains why entrepreneurship is often associated with a society of prosperity (Covin \& Wales, 2019; Farini, Puya, Soleymani, \& Hosseinini, 2012; Murphy, Liao, \& Welsch, 2006; Oliveira, Melo, \& Muylder, 2015). Economists understand that entrepreneurship is what powers the economic engine (Acs, Desai, \& Hessels, 2008; Audretsch, 2012; Dorobat \& Topan, 2015; Filion, 1997; Kuratko, 2011; Vuong et al., 2016; Wakkee, Veen, \& Eurling, 2015). Baron and Shane (2007) and Wakkee et al. (2015) stressed, however, that entrepreneurship can only contribute to this development if companies succeed.

Vale, Corrêa, and Reis (2014) also affirmed that the opening of a new business is related to factors that go beyond the opportunity (or necessity) logic, since they depend, among other factors, on personal attributes. Indeed, the development of studies aimed at understanding the subjective concept of entrepreneurship and identifying attributes that form the entrepreneur profile is relevant (Ching \& Kitahara, 2015; Filion, 1999).

For Mintzberg (2003), Slack and Parent (2006), and GEM (2013), a limitation of small businesses is the fact that the small-business entrepreneur usually assumes full responsibility for the company's management, having to answer to every kind of situation, from the very important to the trivial. According to Wang et al. (2011), this creates, as a side effect, a deficiency in developing strategic planning, which, Oliveira et al. (2013) and Sa and Chai (2020) stated, is a symptom of a lack of professionalism. It is worth mentioning that the strategy alone corresponds to one of the personal values of small entrepreneurs, in terms of beliefs and assumptions for action. However, the action based on the implementation of systematic plans, corresponds to strategic planning, which characterizes the dimension of professionalism.

The findings of Martins, Maccari, Campanario, and Almeida, (2008), Muzzio (2013) and Sa and Chai (2020) showed that literature on professionalization is limited and primarily focuses on family business. Indeed, while family businesses are common in the organizational context, they have a reputation of not being professional, with emotional aspects that may interfere in business objectivity. In addition, nepotism tends to preclude meritocracy and leads to difficulties in firing employees due to their family ties, which leads to poor management (Belmonte \& Freitas, 2013; Muzzio, 2013).

In this context, professionalization disciplines family members by establishing nonpersonalized rewards (Steward \& Hitt, 2012). Although professionalization can be interpreted as a requirement 
to fight competition (Muzzio, 2013), the process of professionalization often creates conflicts stemming from a need to break from values, since the founding family prioritizes harmony in social relations while the organizational system has a spirit of competitiveness (Lescura, 2009). The values attached to the business founder lose strength in favor of values associated with efficiency, which symbolizes professionalization (Muzzio, 2012).

Wakkee et al. (2015) highlighted the enlargement of market share, via either the acquisition of new companies or an internalization process, as a promissory path for companies to grow. The search for improved operational efficiency, which, according to Muzzio (2012), is linked to professionalism, was also mentioned by Wakkee et al. (2015), though they also asserted that an exclusively internal vision generates limited results in terms of organizational growth.

Belmonte and Freitas (2013), in analyzing the degree of professionalism of two businesses, identified several elements linked with professionalization, such as formal strategic planning and human resource policies that, besides legal benefits, offer a career path that is in accordance with the employee's performance. Furthermore, O'Gorman, Bourke, and Murray (2005) stated that a short-term focus and the multifunctional characteristic may be seen as indicators of a lack of professionalism of the management.

\section{METHOD}

To achieve the objective of identifying an inventory of personal values of small-business entrepreneurs, a descriptive quantitative approach was adopted. In descriptive research a series of information about the object under study is collected in order to inform about values, situations, or behaviors of the analyzed population. According to Gunther (2003), the survey method is among the main ways to comprehend human behavior in a context of empirical social science. It basically consists of asking people about what they think or do. Baker (2001) and Fink (2012) defined the survey as a data collection method that is used to describe individuals' feelings, values, and behaviors.

The research object is Brazilian entrepreneurs. According to GEM (2016), considering the population between 18 and 64 years old in Brazil (approximately 133.3 million people), 36\% are entrepreneurs (that is, about 48 million people).

Carland et al. (1984) suggested that research about entrepreneurs may not bring sound conclusions if the sample is mistakenly compounded by including nonentrepreneurs. Carton et al. (1998) and Bruyat and Julien (2000) stated that the lack of agreement about who qualifies as an entrepreneur has led researchers to select nonhomogeneous samples, inducing them to draw erroneous conclusions. The concept of entrepreneur adopted in this article is in line with that of authors such as Carland et al. (1984), Gartner (1989), Sharma and Chrisman (1999), Peredo and Mclean (2006), and Verga and Silva (2014), who describe the entrepreneur as the founder of a new business, someone who creates and then operates a company-though not necessarily innovatively. The authors of the current study believe that the adoption of other criteria to filter the sample would overly reduce the size of the population and sample, making the data collection process difficult. 
The research sample is compounded by the southern small-business entrepreneurs, which makes the sample a convenience and nonprobabilistic one. The nonprobabilistic sample entails operational simplicity as its advantage that, according to Selltiz (1974) and Viana (2011), compensates for the limitation of not being able to generalize the results. The small-business entrepreneur, in this research, can be thought of as a shopkeeper or service provider, whose own business is their primary source of income and demands most of their time (Carland et al., 1984), who has up to nine employees and revenues up to $\mathrm{R} \$ 360,000.00$ (equivalent to $\mathrm{U} \$ 93,750$ ) per year, and who meets the criteria of Brazilian Complementary Law 123 from December 2006 that classifies their business as small and allows the owner to be part of the integrated tax regime.

A questionnaire was used to collect the data. Gunther (2003) defined a questionnaire as a group of questions about a certain topic that does not test the ability of the respondent, but measures their opinion, interests, and personality aspects. Gunther (2003) clarified that a questionnaire may be conducted through personal interaction with the researcher, or may be self-completed. In the current study, the latter approach was used.

The data-collection process occurred between May 15 and June 15, 2017. A total of 54 questionnaires were received, out of 100 originally sent out; however, four were incomplete and thus had to be removed, leaving 50. This return rate is above that stipulated by Gunther (2003) and Groves (2011), who have highlighted that low return rate from respondents is one of the challenges of research utilizing this technique. In order to ensure a satisfactory rate of return, an attempt was made to previously notify and charge respondents about sending and completing the questionnaire, which was only possible due to the use of intermediaries, formed by professionals who have direct access to the small entrepreneurs such as accountants and consultants.

In order to ensure a satisfactory return rate, the respondents as shown in Table 1 were previously were previously notified that they would be receiving the questionnaire and were later reminded about the importance of filling it out. This was possible due to the use of intermediaries, who comprised professionals with direct access to target respondents for the research, who were all accountants and consultants.

Table 1

Socio demographic data

\begin{tabular}{lll}
\hline \multirow{2}{*}{ Gender } & Male & $56 \%$ \\
& Female & $44 \%$ \\
\hline \multirow{2}{*}{ Age (years) } & $18-25$ & $2 \%$ \\
& $26-35$ & $12 \%$ \\
& $36-50$ & $66 \%$ \\
Education level & $51-60$ & $18 \%$ \\
& Above 60 & $2 \%$ \\
\hline \multirow{2}{*}{ Marital status } & High school & $38 \%$ \\
& College & $62 \%$ \\
\hline \multirow{2}{*}{ Sector } & Single & $22 \%$ \\
& Married & $66 \%$ \\
\hline
\end{tabular}

Source: Authors. 
BBR

18

474

The questionnaire was based on the literature review (Chart 1), from which 10 dimensions of entrepreneurs' personal values were identified: (1) capitalist values; (2) ethics; (3) family history; (4) risk propensity; (5) innovativeness; (6) independence; (7) business affinity; (8) problemsolving ability; (9) centralization; and (10) strategy. In Chart 1 it is also possible to identify the dimension of professionalism and its indicators.

Chart 1

Variables and indicators

\begin{tabular}{|c|c|}
\hline Dimension & Source/ Indicators \\
\hline Capitalist Values & $\begin{array}{l}\text { Schwartz (1992, 1994); Bruna Junior et al (2010); Dolan and Altman (2012), Procópio } \\
\text { (2012), Focus Group. } \\
\text { Being rich is important to him. He likes to be recognized for his professional success. } \\
\text { He believes that the company should provide him with money so that he can enjoy the } \\
\text { pleasures of life. }\end{array}$ \\
\hline Ethics & $\begin{array}{l}\text { Schwartz (1992, 1994); Tan, Williams and Tan (2005); Dolan and Altman (2012) and } \\
\text { Procópio (2012), Focus Group. } \\
\text { He respects labor and tax legislation, even when he disagrees or feels hurt by it. Therefore, } \\
\text { it does not make informal agreements with employees. He believes that the current labor } \\
\text { legislation generates opportunistic lawsuits and is therefore favorable to its reform. He is } \\
\text { not able to work fully within the legal framework all the time. }\end{array}$ \\
\hline Family History & $\begin{array}{l}\text { Julien et al. (2010); Artuso et al (2012); Silva, Couto and Coelho (2012) and Vuong, Do } \\
\text { and Vuong (2016) and Focus Group. } \\
\text { He comes from a family whose parents also owned a business. His parents did not advise } \\
\text { him to be employed. Your parents have always encouraged you to be an entrepreneur. }\end{array}$ \\
\hline Business Affinity & $\begin{array}{l}\text { Boaventura and Melo (2012); Costa, Caetano and Santos (2016). } \\
\text { He has affinity with his area of expertise. He does not think about changing his industry. } \\
\text { He likes his job. }\end{array}$ \\
\hline Risk & $\begin{array}{l}\text { Carland, Boulton and Carland (1984); Schwartz (1992, 1994); Filion (1997); Kuratko } \\
\text { (2011); Silva, Couto and Coelho (2012); Filardi, Barros and Fischmann (2014); Arafeh } \\
\text { (2016); Costa, Caetano and Silva (2016) and Mattingly and Kushev (2016); Focus Group. } \\
\text { He has a willingness to take risks. He needs to manage billing fluctuations, as sales in his } \\
\text { segment are seasonal. He is cautious when assessing risk and would never compromise the } \\
\text { company's financial structure. He prefers not to try to expand the business if it threatens his } \\
\text { financial balance and quality of life. }\end{array}$ \\
\hline Innovativeness & $\begin{array}{l}\text { Schumpeter (1934); Schwartz (1992, 1994); Filion (1999); Peredo and Mclean (2006); } \\
\text { Leitáo, Sasch and Thurik (2011); Kuratko (2011); Moraes et al (2012); and Arafeh } \\
\text { (2016); Focus Group. He considers innovation to be very important for maintaining } \\
\text { competitiveness and for the survival of the company. He constantly questions the efficiency } \\
\text { of traditional processes. He seeks new forms of relationship with the customer. }\end{array}$ \\
\hline Independence & $\begin{array}{l}\text { Stevenson and Jarilho (1990); Schwartz (1992, 1994); Carton, Hofer and Meeks (1998); } \\
\text { Sesen and Pruett (2014) and Costa, Caetano and Santos (2016); Focus Group. } \\
\text { It is important for him to make his own decisions freely. He considers it important for } \\
\text { the company to have someone at the top of the hierarchy with autonomy to eliminate } \\
\text { deadlocks.He doesn't like his work to depend on other people. }\end{array}$ \\
\hline $\begin{array}{l}\text { Problem-solving } \\
\text { ability }\end{array}$ & $\begin{array}{l}\text { Gartner (1988) and Arafeh (2016); Focus Group. } \\
\text { He has the ability to solve administrative problems. He has difficulty solving problems } \\
\text { related to people management. He spends a lot of time solving unforeseen problems. }\end{array}$ \\
\hline
\end{tabular}


Chart 1

Cont.

\begin{tabular}{|c|l|}
\hline Dimension & \multicolumn{1}{c|}{ Source/ Indicators } \\
\hline Centralization & $\begin{array}{l}\text { Mintzberg (2003); O'Gorman, Bourke and Murray (2005); Slack and Parent (2006) and } \\
\text { GEM (2013); Focus Group. } \\
\text { He is responsible for several departments. He finds it difficult to leave the company because } \\
\text { he has no substitute. He does not delegate the financial area due to the absence of control } \\
\text { mechanisms. }\end{array}$ \\
\hline Strategy & $\begin{array}{l}\text { Carland, Boulton and Carland (1984); O'Gorman, Bourke and Murray (2005); Mattingly } \\
\text { (2015) and Wakkee, Veen and Eurlings (2015); Sa and Chai (2020); Focus Group. }\end{array}$ \\
$\begin{array}{l}\text { He is more concerned with operational efficiency than with competitor actions. He has no } \\
\text { long-term projects. It does not have a formalized strategy. }\end{array}$ \\
\hline Professionalism & $\begin{array}{l}\text { Bruna Junior et al (2010); Muzzio (2012, 2013) and Belmonte and Freitas (2013). } \\
\text { It rewards employees based on performance appraisal. It rationalizes decision-making } \\
\text { based on analysis and does not rely on intuition alone. He seeks theoretical knowledge } \\
\text { through courses in the field of Administration. It adopts management tools, has pre-defined } \\
\text { processes and monitoring criteria. He understands accounting, especially tax mechanics. }\end{array}$ \\
\hline
\end{tabular}

Source: The Authors

After conducting the questionnaire, a focus group was then conducted. According to Oliveira and Freitas (1998), focus groups are useful in quantitative studies that adopt the survey approach, as they may exploit and elicit relevant issues, besides helping to clarify any unclear aspects regarding the theme of the research.

Gondim (2003) and Trad (2009) stated that a focus group can be a complementary strategy in quantitative research. It is used to understand the perceptions, opinions, and feelings toward a certain theme and in a certain environment of social interaction, in order to support the building or elaboration of a data-collection tool.

For Trad (2009), participants of a focus group must be associated with the central theme of the study in order to be able to contribute in a competent way toward the data. Therefore, in this study, a consultant in small and medium enterprises, a professor of entrepreneurship from a traditional business school in Rio Grande do Sul, and a couple of entrepreneurs took part in the focus group, which lasted two hours. The focus group helped significantly in the adjustment and analysis of the questionnaire indicators, for each personal value focused on the small entrepreneur. It was curious to note that the consultant for small and medium-sized enterprises stated that the topic of this research is relevant and that little is known about the personal values of small entrepreneurs in business. This added even more security to the researchers, who had detected this gap in the literature review. This focus group participants helped to adjust the semantics and offered extra indicators for the dimensions, especially professionalism. The focus group occurred before the field study.

In addition to Schwartz's instrument, the values were measured implicitly; the respondent compared how much another respondent looked like them, and, based on the similarity reported, the respondents' values could be inferred. The respondents classified each item in the questionnaire using a five-point Likert-type scale, wherein $1=$ "he doesn't look anything to me" and 5 = "he looks very much like me."

Structural equation modeling was performed using Partial Least Squares - Structural Equations Modeling (PLS-SEM). PLS is an appropriate tool for validating exploratory models, as it allows satisfactorily estimating structural relationships and making predictive causal analyzes, even with small samples. Structural equation modeling (SEM) was used to relate the entrepreneurs' personal 
BBR

18

476

values to their business professionalization. Once the model has not been sustainable, it was concluded that professionalism is part of the group of personal values belonging to entrepreneurs, and its dimensions were included in the data-collection instrument used in this research.

Campos and Porto (2010) indicated that the advancement of theories about personal values is directly related to the quality of empirical work performed by researchers around the globe in describing the structure of values in different cultures, and to increased sophistication and improvement in the measurement instrument in relation to assessing the values according to cultural aspects.

The creation of the questionnaire for this study required semantic validation, which was performed by means of a pretest conducted with a group of 10 specialists, including doctors, graduate management students, and entrepreneurs. This is in line with Silva's (2014) approach, as he also submitted his instrument for evaluation by 10 specialists in order to verify the clarity and objectivity of the text, which he deemed essential to improve comprehension. In the current study, the pretest resulted in the need for small modifications to some of the items.

The sample for the main study comprised 50 respondents. However, there is no consensus regarding the size of this sample. Hair (2009), recommends a minimum of 5 respondents per question. Iacobucci (2010), on the other hand, indicates a simplistic rule of $n>200$ for the sample size, however, it goes further by informing that analyzes can be done comfortably even with small samples, such as 50 to 100 . A small (n) sample of a large $(\mathrm{N})$ population, as in this research, finds validity in the Central Limit Theorem, in which the distribution tends to be normal since $n>$ 30 (Freund, 2006). Drawing from the residual diagram from SPSS 21 with professionalism as a dependent variable, it was possible to observe a symmetrical distribution that stood for normality. It was also observed from the residual analysis that there was no outliers or non-linear trends. The general pattern of the relationship was described satisfactorily by the straight line, as there was no marked deviation from linearity in the point diagram, which allowed the conclusion that the description of the existing relationship was adequately in line with Freund (2006). Structural equation modeling was performed using Partial Least Squares - Structural Equations Modeling (PLS-SEM). PLS is an adequate tool for validating exploratory models, as it allows satisfactorily estimating structural relationships and making predictive causal analyzes, even with small samples. Therefore while 50 is a small sample, it is suited to statistical analysis (Iacobucci, 2010; Freund, 2006). Most of the entrepreneurs were based in Rio Grande do Sul, in the southern part of Brazil (Passo Fundo city), and approximately 30\% of the questionnaires were sent to entrepreneurs in other cities in the northern region of the state of Rio Grande do Sul (RS), and also the city of Caxias do Sul (RS). The hallmark of Brazilian culture and values is diversity and heterogeneity (Alcadipani \& Crubellate, 2003), which contributes to legitimize the regions chosen and the reality of their small entrepreneurs, that can enrich the diagnosis of entrepreneurship in the Brazilian context. The entrepreneurs' values were described via a descriptive statistical analysis using the Statistical Package for Social Science (SPSS 21) and SmartPLS 3.0.

\section{RESULTS}

Before evaluating a structural model, it is necessary to ensure that the measurement model contains some precision indicators. In order for the model to be considered acceptable, the 
compound reliability (CR) must be greater than 0.70 and the average extracted variance (AVE) greater than 0.50 .

For Hair (2009), CR and AVE are used to evaluate the quality of psychometric structural models, whose calculations are performed based on parameters estimated through SEM. SmartPLS 3.0 was used to reveal the factor loading of each item from the data-collection instrument in relation to its corresponding dimension. The results are shown in Table 2.

Table 2

Cross-Load Matrix

\begin{tabular}{|c|c|c|c|c|c|c|c|c|c|c|}
\hline 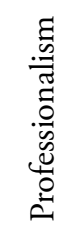 & 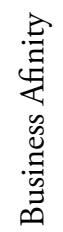 & 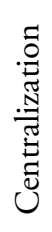 & 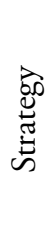 & 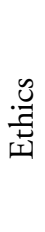 & 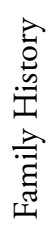 & 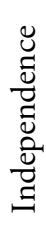 & 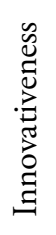 & 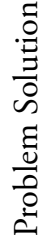 & 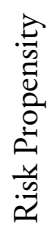 & 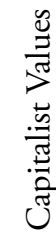 \\
\hline
\end{tabular}

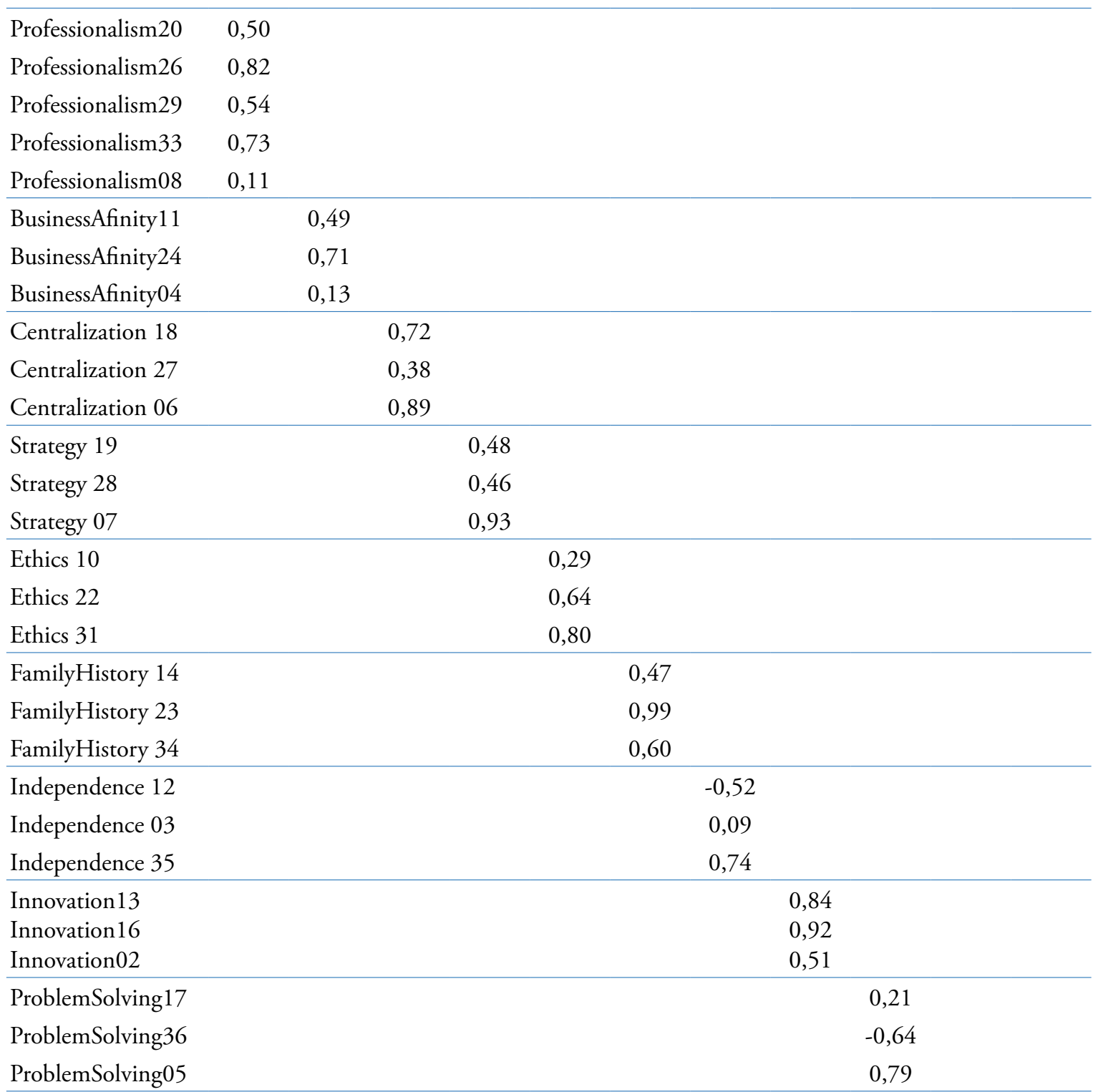


BBR

18

478

\begin{tabular}{|c|c|c|c|c|c|c|c|c|c|c|c|}
\hline & 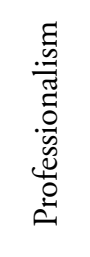 & 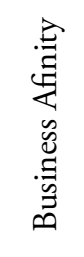 & 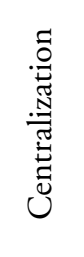 & 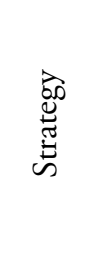 & 苞 & 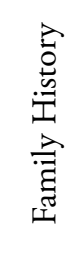 & 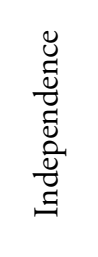 & 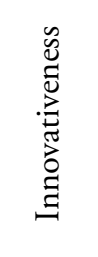 & 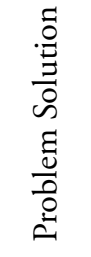 & 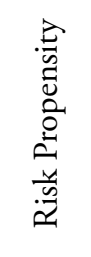 & 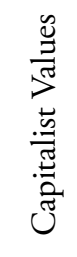 \\
\hline Risk 01 & & & & & & & & & & 0,07 & \\
\hline Risk 15 & & & & & & & & & & 0,34 & \\
\hline Risk 25 & & & & & & & & & & 0,96 & \\
\hline Risk 32 & & & & & & & & & & 0,46 & \\
\hline CapitalistValues21 & & & & & & & & & & & 0,68 \\
\hline CapitalistValues30 & & & & & & & & & & & 0,74 \\
\hline CapitalistValues09 & & & & & & & & & & & 0,47 \\
\hline CR & 0,69 & 0,05 & 0,72 & 0,68 & 0,61 & 0,74 & 0,02 & 0,81 & 0,06 & 0,55 & 0,67 \\
\hline AVE & 0,35 & 0,25 & 0,48 & 0,44 & 0,37 & 0,52 & 0,30 & 0,61 & 0,36 & 0,31 & 0,41 \\
\hline
\end{tabular}

Source: Authors.

The values of the factor loadings, in general, obtained a low score. The reliability of the model was less than $70 \%(\mathrm{CR}<0.7)$ for most dimensions, except for centralization, family history, and innovativeness. Only family history and innovation presented AVE values above $50 \%$. There were, therefore, several items with low loads (AVE $<0.5)$. It is thus concluded that the model can not be used without these precision indicators. Among the possible causes of the inadequacy of the model is the small sample size $(\mathrm{n}=50)$.

While in Smart PLS 3.0 as shown in Figure 1 the latent variables the latent variables measurement model was not consistent, because the values of the factor loadings were low or negative, in SPSS the factor loadings were not influenced by the structural model, which is a solution that guarantees the suitability of the model's scores that were saved for multiple linear regression. Therefore, after analyzing a latent variable in SPSS, the "main component" was extracted. After this procedure, the factor scores were saved, since the factor loadings were satisfactory for use in multiple linear regression. After calculating the factor load of each dimension of values in the SPSS, the respective precision indexes were obtained using a spreadsheet configured with the AVE and CC formulas, since the SPSS does not provide the results of the AVE and CC automatically (Valentin and Damásio, 2016).

The descriptive statistical analysis started with identifying the mean of the value dimensions, as well as other statistical data such as standard deviation and variance, as shown in Table 3.

After calculating the means of the value dimensions, it was observed that family history, regarding the existence of entrepreneurial parents in the family, was the only dimension to score below three points; this dimension also had the lowest mean (2.36 points in a scale from 1 to 5$)$. Based on this data, it may be inferred that most of the researched small-business entrepreneurs did not inherit their companies, but founded them, being pioneers in the family when regarding opening their own business; this might explain the growth of new businesses referred to by Ferreira et al. (2011) and Filardi et al. (2014). 


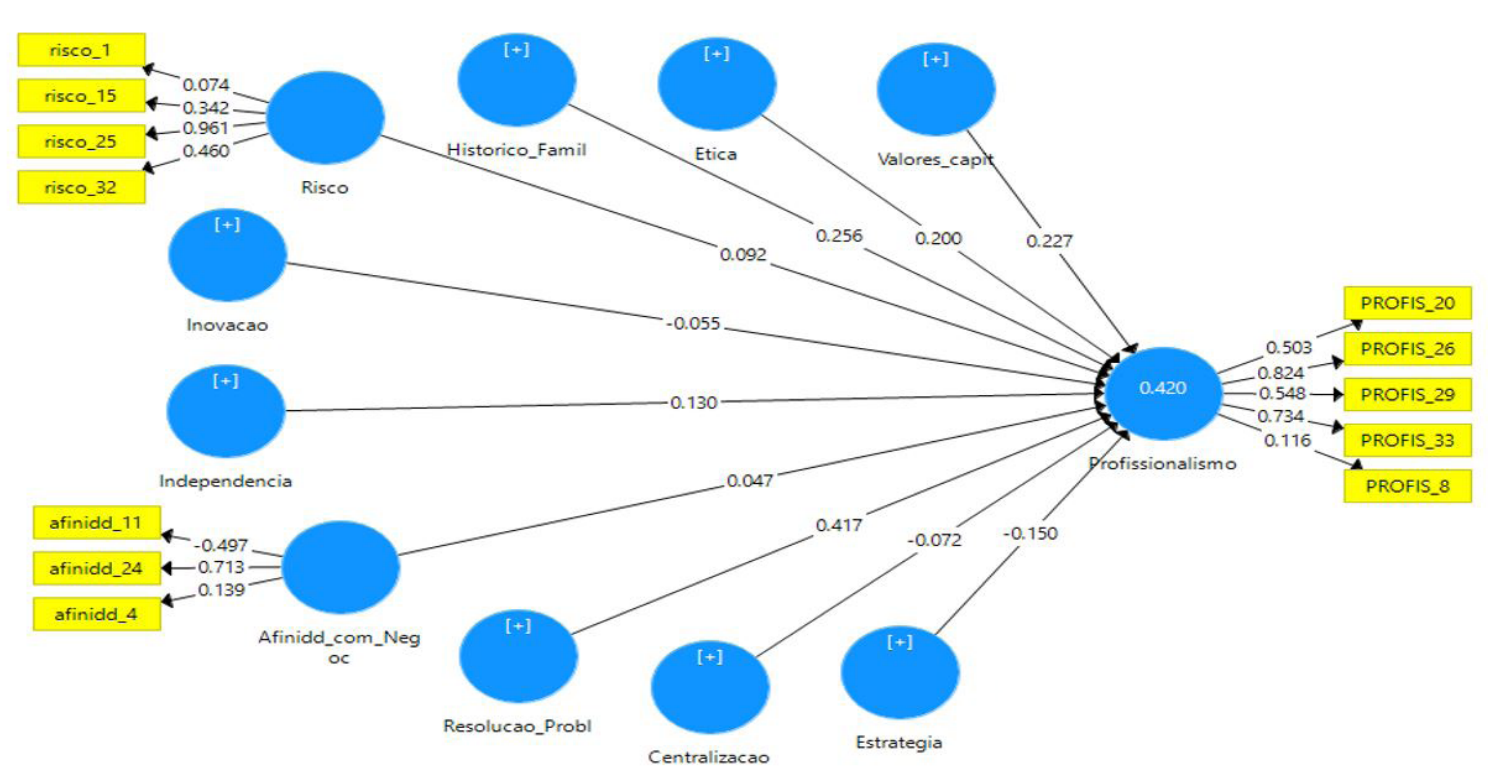

Figure 1. Structural Mensuration Model

Source: The Authors based on SmartPLS 3.0.

Table 3

Mean of the dimensions' values

\begin{tabular}{lcccccccc}
\hline Dimension & $\mathrm{N}$ & Range & Minimum & Maximum & Mean & Std Error & Std Deviation & Variance \\
\hline Capitalist Values & 50 & 3.33 & 1.67 & 5.00 & 3.42 & 0.10 & 0.77 & 0.60 \\
Ethics & 50 & 3.33 & 1.67 & 5.00 & 3.38 & 0.10 & 0.76 & 0.59 \\
Family History & 50 & 4.00 & 1.00 & 5.00 & 2.36 & 0.15 & 1.08 & 1.18 \\
Risk & 50 & 3.00 & 1.75 & 4.75 & 3.50 & 0.08 & 0.63 & 0.39 \\
Innovativeness & 50 & 3.00 & 2.00 & 5.00 & 3.98 & 0.10 & 0.73 & 0.54 \\
Independence & 50 & 3.00 & 2.00 & 5.00 & 3.60 & 0.10 & 0.76 & 0.59 \\
Business Affinity & 50 & 4.00 & 1.00 & 5.00 & 4.24 & 0.11 & 0.77 & 0.60 \\
Problem Solving & 50 & 2.67 & 2.00 & 4.67 & 3.26 & 0.08 & 0.59 & 0.35 \\
Centralization & 50 & 3.33 & 1.67 & 5.00 & 3.50 & 0.12 & 0.91 & 0.83 \\
Strategy & 50 & 3.00 & 1.33 & 4.33 & 3.26 & 0.11 & 0.79 & 0.62 \\
Professionalism & 50 & 3.20 & 1.60 & 4.80 & 3.35 & 0.09 & 0.69 & 0.47 \\
\hline
\end{tabular}

Source: Authors.

Business affinity was the only dimension with a value above three points; this also had the highest mean (4.24), revealing that most of the researched entrepreneurs like the work they perform and considered familiarity with their segment as a relevant factor in deciding to open their own business. This is in line with recommendations by authors such as Boaventura and Melo (2012) and Costa et al. (2016).

One of the items in the questionnaire attributed importance to innovation (Kuratko, 2011; Leitão et al., 2011; Schumpeter, 1934; Williamson et al. 2019). In the focus group, all participants classified innovation as essential, especially during periods of economic recession, to increase sales. Participants stated that entrepreneurs can no longer focus on production only, but must 
follow market trends in order to remain relevant. However, the participants also clarified that innovation is not necessarily about the product, but can also be expressed in terms of forming new relationships with clients, or reinventing operational processes.

Another item connected caution to risk evaluation, as recommended by Kuratko (2011). For participants of the focus group, risk is generally taken in a responsible way. Although the financial return is directly proportional to the risk taken, it is preferable not to compromise the company's financial structure.

In the professionalism dimension, it was revealed for one item, due to its low mean score, that the small-business entrepreneurs were not aware of the accounting legislation to which their company is subject. In this context, the focus group raised an interesting debate, in which hard accusations were directed toward the Brazilian taxation system. Very high taxes inhibit the investment capacity of companies, and the government is considered by the respondents to be inefficient at managing revenue from taxes, since this should be invested in infrastructure but often ends up being spent on unethical practices due to corruption. Nevertheless, entrepreneurs need to understand the taxation system in order to pay less - not by misappropriation, but by making use of tax planning via accounting assistance. However, this aspect highlights another problem: accountants often do not have time to answer client requests due to the demands imposed by the government.

Therefore, it is considered that the lack of professionalism is one of the factors with explanatory power as to the high rates of early mortality in small companies brought by Julien (2010), Eckert et al. (2013) and Sa and Chai (2020), in which one fifth of companies close their activities in the first two years. Moreover, the percentage of companies that are unable to keep operating can double and about 75\% of new businesses do not survive beyond 5 years (Salamouris, 2013). Filardi et al. (2014) and Wang and Jessup (2014) also investigated the main factors associated with these indexes and concluded that characteristics directly linked to the performance of the entrepreneur at the head of the business proved to be decisive for the survival of the enterprises. Based on these authors, one can contemplate the intensity of these personal values, which can influence the performance of small entrepreneurs. From table 3, it can be seen that professionalism tends not to stand out and remains around 3, even if the value "Business Affinity " has obtained a higher note (4.24). This suggests that professionalism in the research sample tends to detach from supposedly linked personal values, such as "Business Affinity”.

The participants of the focus group added that, although they aim to meet all legal requirements, the reality of the market is cruel; often, competitors sell merchandise without submitting receipts so that they can pay fewer taxes, making other companies compete by means other than price. It is recommended that entrepreneurs search for information and knowledge about the taxation system in their country in order to improve their professionalism and enjoy the benefits of tax planning.

In Table 4, correlations higher than 0.25 are considered significant at $10 \%$, and correlations higher than 0.28 are considered significant at $5 \%$. The results show that only two latent variables obtained a significant relation with professionalism: ethics, which yielded $\mathrm{r}=0.25(\mathrm{p}<0.10)$, and capitalist values, for which the results were $r=0.29(p<0.05)$. It is also worth noting the correlation of 0.50 between centralization and capitalist values, as the largest correlation contained in Table 4, which indicates that small-business entrepreneurs may follow a trend towards centralization as they seek to increase their revenue or profit margin. Underlying this behavior may be a need for control and dominance of the entrepreneur over their business. 
Table 4

Correlation among the scores of the latent variables

\begin{tabular}{|c|c|c|c|c|c|c|c|c|c|c|c|}
\hline & 1 & 2 & 3 & 4 & 5 & 6 & 7 & 8 & 9 & 10 & 11 \\
\hline 1. Professionalism & 1.00 & & & & & & & & & & \\
\hline $\begin{array}{l}\text { 2. Business } \\
\text { Affinity }\end{array}$ & -0.05 & 1.00 & & & & & & & & & \\
\hline 3. Centralization & 0.08 & 0.03 & 1.00 & & & & & & & & \\
\hline 4. Strategy & -0.05 & 0.15 & 0.06 & 1.00 & & & & & & & \\
\hline 5. Ethics & 0.25 & 0.27 & 0.17 & 0.15 & 1.00 & & & & & & \\
\hline 6. Family History & 0.17 & -0.07 & 0.20 & 0.00 & 0.03 & 1.00 & & & & & \\
\hline 7. Independence & 0.09 & 0.35 & 0.08 & 0.17 & 0.32 & 0.18 & 1.00 & & & & \\
\hline 8. Innovativeness & 0.08 & 0.00 & 0.01 & -0.24 & 0.16 & 0.14 & 0.00 & 1.00 & & & \\
\hline $\begin{array}{l}\text { 9. Problem } \\
\text { Solving }\end{array}$ & 0.05 & -0.27 & 0.32 & 0.39 & 0.00 & 0.29 & -0.10 & -0.07 & 1.00 & & \\
\hline 10. Risk & -0.03 & 0.25 & 0.30 & 0.05 & 0.14 & -0.08 & -0.02 & -0.07 & -0.14 & 1.00 & \\
\hline $\begin{array}{l}\text { 11. Capitalist } \\
\text { Values }\end{array}$ & 0.29 & -0.14 & 0.50 & -0.11 & 0.14 & 0.37 & -0.05 & 0.07 & 0.11 & 0.10 & 1.00 \\
\hline
\end{tabular}

Source: Authors.

Capitalist values was the only independent variable in the regression with statistical significance that was found to influence professionalism; in the words of Bruna Junior et al. (2010), the company provides the money that allows the entrepreneur to access the standards of preference driven by capitalist values. Procópio (2012) stated that, in a capitalist society, money can not only have a positive meaning for most people who need to pay for their comfort, but also form a guideline for conduct. The social agent, in this case represented by the entrepreneur, acts in accordance with what the market-centered society preaches. Competitiveness and the search for professional success and wealth are behaviors that may be guided by the strong values in capitalist society; thus, the entrepreneur follows the direction approved by these capitalist values (Bruna Junior et al., 2010; Covin \& Wales, 2019; Wiklund et al., 2019; Tornikoski and Maalaoui, 2019; Freire-Gibb \& Gregson, 2019; Sa \& Chai, 2020; Manning, Stokes, Tarba, \& Rodgers, 2020).

Table 5

Linear Regression Model

\begin{tabular}{cccccc}
\hline $\begin{array}{c}\text { Model } \\
\text { a.Dependent variable: } \\
\text { Professionalism }\end{array}$ & Unstandardized Coefficients & $\begin{array}{c}\text { Standardized } \\
\text { Coefficients } \\
\text { B }\end{array}$ & Std.Error & Beta & Sig. \\
\hline (Constant) & $5,290 \mathrm{E}-018$ &, 137 & &, 000 & 1,000 \\
Capitalist Values &, 293 &, 138 &, 293 & 2,121 &, 039 \\
\hline
\end{tabular}

Source: Authors from SPSS.

The predictive power of linear regression was attested by $\mathrm{R}^{2}=0.086$, called the determination coefficient, which was defined by Hair (2009) as an adjustment measure that varies between 0 and 1 and indicates how much a statistical model can explain the relationship between the variables existing. 
The ANOVA test was also significant, since $\mathrm{p}=0.039$ and, therefore, $\mathrm{p}<0.05$, demonstrating that at least one regression coefficient such as the independent variable of Capitalist Values influences the Professionalism as dependent variable. Although this research was exploratory and does not allow generalizations, the finding that only one of the 10 independent variables adopted in this study was found to be statistically influential on professionalism constitutes the study's main theoretical contribution, since it rethinks professionalism as a personal value, rather than a dependent variable, like the others, independent, emancipated and sovereign.

Drawing from Vignochi, Lezana and Camilotti (2014) and Sa and Chai (2020), the main implication of this research remains on the influence of personal values in entrepreneurial action, that can support the creation of new tools that assist in the training of entrepreneurs. Observing the research results and considering the sample limitation, one can observe the relevance of personal values and their implications for entrepreneurship. As the personal values of the entrepreneur are individual, these same values become the organizational values of small businesses.

The results showed that professionalism does not seem to be significantly correlated with the majority of the personal values of small entrepreneurs, as was supposed. Nevertheless, the fact that the small entrepreneur has an "business affinity" for instance is no guarantee that this will result in professionalism. This was not opposed to literature (Zuccari and Belluzzo, 2016; Rokeach, 1973; Schwartz, Cieciuch, Vecchione, Davidov, Fischer, \& Konty, 2012; Granjo \& Peixoto, 2013; Tornikoski \& Maalaoui, 2019; Manning, Stokes, Tarba, \& Rodgers, 2020) , but it added a new perspective on professionalism.

Therefore, the results of this research pointed out that professionalism may not be a dependent variable in relation to the other personal values of the small entrepreneur. It opens up the possibility that professionalism is actually a personal value carried by the small entrepreneur, capable of being decisive in business. This is consistent with the finding that the small entrepreneurs carry their own personal values to their business and that this has been little researched in the literature. In addition, professionalism itself could also be a personal value that aligns itself with other values in a random and simultaneous way, without a specific dependency relationship. The small entrepreneur's personal values seem to coexist, with their respective relevance to business, without imposing a dependency relationship between these variables. However, the diagnosis of the personal values of each entrepreneur implies management guidelines and interventions that are less generic and more customized to support this professional.

\section{CONCLUSIONS}

In general, this research presents a positive outcome in reaching its stipulated goal of describing the inventory of Brazilian small-business entrepreneurs' personal values. Results showed that only capitalist values were statistically significant enough to influence professionalism. This relationship between professionalism and capitalist values reveals the possible perception of entrepreneurs that professionalization of management positively influences managerial aspects linked to the business's profitability. It is also possible to infer that the construct Professionalism, although in step with the construct Capitalist Values, does not depend on the entrepreneur's other personal values such as the constructs Ethics, Family History, Risk, Innovativeness, Independence, Affinity with Business, Problem Solving abilities, Centralization and Strategy. Therefore, it seems that the elaboration of any hypothesis in the sense that these values influence Professionalism would not find statistical support.

The creation of the data-collection instrument demanded (1) an exhaustive investigation of the national and international literature to extract entrepreneurs' personal values and divide 
them into 11 dimensions: professionalism, business affinity, centralization, strategy, ethics, family history, independence, innovation, problem solving, risk and capitalist values; and (2) a complementary focus group to ratify the findings from the literature and offer insights to elaborate new items to measure values. This led to the creation of the Entrepreneur Personal Values Questionnaire, which comprises 36 items that measure, using a five-point Likert-type scale, each of the dimensions of values.

It is important to remember that the instruments available for measuring personal values do not consider the specifics of the entrepreneur. In terms of practical implications, the instrument used for data collection in this study offers prospects to create a new tool for supporting entrepreneurs based on their personnel values; however, in order to validate this tool, entrepreneurs' personal values should be considered to identify weaknesses in areas such as strategy, innovation, or risk management. Therefore, among the practical implications it would be effective to mention the personalization of training according to the value profile of the small entrepreneur; the realistic diagnosis of the small entrepreneur's beliefs and assumptions that can affect the conduct of business; the elimination of generic approaches to deal with the preparation of small entrepreneurs in terms of materials, lectures and training; the valuation of personal values in a degree of importance equivalent to the business plan, since the personal values of the small entrepreneur become their organizational values.

Some limitations of the study should also be noted. The first pertains to researcher bias (Gondim, 2003). It is believed that, in the science field, impartiality contributes to reliability regarding results; however, every researcher has values and beliefs that are inseparable from the cultural historical context in which the researcher is inserted and that, therefore, might compromise the researcher's objectivity in interpreting data, leading to attribution of most convenient meaning to the data revealed. Thus, different researchers may interpret the same data differently. This limitation, however, is considered to be one of a broad spectrum, since it is applicable to any scientific research, including that of a quantitative nature.

Considering that Brazil has great cultural diversity, it is recommended that the data-collection instrument be reapplied in other regions using a representative sample of the population. Sambiase et al. (2014) revealed that the restriction of a population segment constitutes a limitation for research that involves personal values, and suggested the development of other studies that include other kinds of samples to contemplate diverse Brazilian geographic regions. Data collection via self-applied electronic questionnaire would not enable the researcher to exercise any control or supervision over the respondents.

\section{REFERENCES}

Acs, Z. J., Desai, S., \& Hessels, J. (2008). Entrepreneurship, economic development and institutions. Small Business Economics, 31(3), 219-234.

Alcadipani, R., \& Crubellate, J. M. (2003). Cultura organizacional: generalizaçóes improváveis e conceituaçóes imprecisas. Revista de Administração de Empresas, 43(2), 64-77.

Anderson, A. R., \& Gaddefors, J. (2016). Entrepreneurship as a community phenomenon: reconnecting meanings and place. International Journal of Entrepreneurship and Small Business, 28(4), 504-518.

Arafeh, L. (2016). A entrepreneurial key competencies' model. Journal of Innovation and Entrepreneurship, 5(26), 1-26.

Armond, A. C., \& Nassif, V. M. J. (2009). A liderança como elemento do comportamento empreendedor: Um estudo exploratório. Revista de Administração Mackenzie. 10(5), 77-106. 
BBR

18

484
Artuso, S. B., Sutter, M. B., Krakauer, P. V. C., Polo, E. F., \& Almeida, M. I. R. (2012). The influences on business students to become entrepreneurs. African Journal of Business Management, 6(42), 10616-10624.

Audretsch, D. (2012). Entrepreneurship research. Management Decision, 50(5), 755-764.

Baker, M. (2001). Selecting a research methodology. The Marketing Review, 1(3), 373-397.

Baron, R. A., \& Shane, S. A. (2007). Empreendedorismo: uma visão do processo. Porto Alegre, RS: Thomson Learning.

Belmonte, V. A. B., \& Freitas, W. R. S. (2013). Empresas familiares e a profissionalização da gestão: estudo de casos em empresas paulistas. Revista de Administração da Universidade Federal de Santa Maria, 6(1),71-90.

Boaventura, M. G., \& Melo, M. C. O. L. (2012). Criação de empresas por microempreendedores. Revista de Administração FACES, 2(2),11-26.

Bruna Junior, E. D., Ensslin, S. R., Ensslin, L., Lezana, A. G. R., \& Garcia, J. R. (2010). Um diagnóstico organizacional com base no ciclo de vida das empresas e características dos empreendedores. Revista CAP, 4(4), 23-31.

Bruyat, C., \& Julien, P. (2000). Defining the field of research in entrepreneurship. Journal of Business Venture, 16(2), 165-180.

Bulgacov, Y. L. M., Cunha, S. K., Camargo, D., Meza, M. L., \& Bulgacov, S. (2011). Jovem Empreendedor no Brasil: a busca do espaço da realização ou a fuga da exclusão? Revista de Administração Pública, 45(3), 695-720.

Campos, C. B., \& Porto, J. B. (2010). Escala de valores pessoais: Validação da versão reduzida em amostra de trabalhadores brasileiros. PSICO, 41(2), 208-213.

Carland, J. W., Boulton, W. R., \& Carland, J. A. C. (1984). Differentiating entrepreneurs from small business owners: A conceptualization. Academy of Management Review, 9(2), 354-359.

Carrão, A. M. R. (2004). Empresas de pequeno porte, espírito empreendedor e auto-emprego In Dowbor L., Furtado, O., Trevisan, L., \& Silva, H. (Eds). Desafios do trabalho. São Paulo: Vozes, 87-98.

Carton, R. B., Hofer, C. W., \& Meeks, M. D. (1998). The entrepreneur and entrepreneurship: Operational definitions of their role in society. Annual International Council for Small Business (pp. 1-12) Sentosa, SE, Singapore.

Castilho, J. J. (1995). Between the desregulating state and the regional networks: Industrial districts in Spain In A. Bagnasco \& C. Sabel (Eds). Small and medium-size enterprises (pp. 69-77). London: Pinter.

Ching, H. Y., \& Kitahara, J. R. (2015). Propensão a empreender: Uma investigação quantitativa baseada nas características empreendedoras de alunos do curso de administração. Revista de Ciências da Administração, 17(43), 99-111.

Cooper, A. C., \& Dunkelberg, W. C. (1986). Entrepreneurship and paths to business ownership. Strategic Management Journal, 7(1), 53-68.

Costa, S. F., Caetano, A., \& Santos, S. C. (2016). Entrepreneurship as a career option: Do temporary workers have the competencies, intention and willingness to become entrepreneurs? The Journal of Entrepreneurship, 25(2), 129-154. 
Covin, J. G., \& Wales, W. J. (2019). Crafting high-impact entrepreneurial orientation research: Some suggested guidelines. Entrepreneurship Theory and Practice, 43(1), 3-18.

Dolan, S. L.; Altman, Y. (2012). Managing by values: The leadership spirituality connection. People and Strategy, 35(4), 20-26.

Dorobat, C. E., \& Topan, M. (2015). Entrepreneurship and comparative advantage. The Journal of Entrepreneurship, 24(1), 1-16.

Eckert, A., Olea, P. M., Dorion, E. C. E., Mecca, M. S., \& Eckert, M. G. (2013). O perfil empreendedor na graduação: um estudo comparativo entre ingressantes e concluintes. Revista Pensamento Contemporâneo em Administração, 7(2), 61-76.

Farini, A. Y., Puya, M., Soleymani, A., \& Hosseinini, G. (2012). How to enhance student's entrepreneurial skills: An academia’s perspective. African Journal of Business Management, 6(11), 4250-4254.

Ferreira, L. F. F., Capra, L. P., Pereira, L. S., Abreu, M. A. S. S., \& Silveira, F. A. (2011, September). Desde os primórdios até hoje em dia: Será que o empreendedor ainda faz o que Schumpeter dizia? Evolução das características empreendedores de 1983 a 2010. Anais do Encontro Nacional da Associação Nacional de Pós-Graduação e Pesquisa de Administração (pp. 35). Rio de Janeiro, RJ, Brasil,.

Filardi, F., Barros, F. D., \& Fischmann I, A. A. (2014). Do homo empreendedor ao empreendedor contemporâneo: Evolução das características empreendedoras de 1848 a 2014. Revista IberoAmericana de Estratégia, 13(3), 123-140.

Filion, L. J. (1997). From entrepreneurship to entreprenology. Usasbe Annual National ConferenceEntrepreneurship: The Engine of Global Economic Development (pp. 13). San Francisco, CA.

Filion, L. J. (1999). Empreendedorismo: empreendedores e proprietários-gerentes de pequenos negócios. Revista de Administração da USP, 34(2), 5-28.

Fink, A. (2012). How to conduct surveys: A step by step guide. London: Sage Publications.

Freire-Gibb, L. C., \& Gregson, G. (2019). Innovation systems and entrepreneurial ecosystems: Implications for policy and practice in Latin America. Local Economy, 34(8), 787-806. https:// doi.org/10.1177/0269094219896096

Frese, M., \& Gielnik, M. M. (2014). The psychology of entrepreneurship. Annual Review of Organizational Psychology and Organizational Behavior, 1(1), 413-438.

Freund, J. E. (2006). Estatística aplicada: Economia, administração e contabilidade. Porto Alegre: Bookman, 2006.

Gartner, W. B. (1989). "Who is an entrepreneur?" is the wrong question. ET\&P-Entrepreneurship Theory and Practice, 13(4), 47-68.

Gerber, M. (1995). The E-myth revisited. New York: Harper Collins.

Global Entrepreneurship Monitor (GEM) (2013). Empreendedores brasileiros: Perfis e percepçôes. São Paulo.

Global Entrepreneurship Monitor (GEM) (2016). Empreendedorismo no Brasil: Relatório Executivo. São Paulo.

Gondim, S. M. G. (2003). Grupos focais como técnica de investigação qualitativa: Desafios metodológicos. Paidéia, 12(24), 149-161. 
BBR

18

486

Granjo, M., \& Peixoto, F. (2013). Contributo para o estudo da escala de valores humanos de Schwartz em professores. Laboratório de Psicologia, 11(1), 03-17.

Groves, R. M. (2011). Three areas of survey research. Public Opinion Quarterly, 75(5), 861-871.

Gunther, H. (2003). Como elaborar um questionário. DF: Brasilia.

Hair, J. F. (2009). Análise multivariada de dados. Porto Alegre: Bookman.

Hofstede, G. (1980). Culture's consequences: International differences in work-related values. London: Sage Publications.

Iacobucci, D. (2010). Structural equations modeling: Fit indices, sample size and advanced topics. Journal of Consumer Psychology, 20(1), 90-98.

Julien, P. (2010). Empreendedorismo regional e economia do conhecimento. São Paulo: Editora Saraiva.

Julien, P., Marchesnay, M., \& Machado, H. V. (2010). Interdisciplinaridade da pesquisa em empreendedorismo e em PME: Por uma teoria empreendedora que contemple diferenças culturais. Revista Gestão e Planejamento, 11(2), 355-368.

Kuratko, D. F. (2011). Entrepreneurship theory, process, and practice in the $21^{\text {st }}$ century. International Journal of Entrepreneurship and Small Business, 13(1), 8-17.

Leitão, J., Lasch, F., \& Thuriki, R. (2011). Globalisation, entrepreneurship and regional environment. International Journal of Entrepreneurship and Small Business, 12(2), 129-138.

Lescura, C. (2009). A dinâmica entre família e organizaçâo: representaçôes sociais acerca das relaçôes de parentesco em uma organização familiar. Dissertação de Mestrado, Universidade Federal de Lavras, MG, Brasil. Retrieved from http://repositorio.ufla.br/bitstream/1/2186/1/DISSERTAÇÃO_A\%20 dinâmica $\% 20$ entre\%20fam\%C3\%ADlia\%20e\%20organização.pdf.

Martens, C. D. P., Freitas, H. (2008). Orientação empreendedora nas organizaçôes e a busca de sua facilitação. Revista Gestão.org, 6(1), 90-108.

Martins, A., Maccari, E. A., Campanario, M. A., \& Almeida, L. M. I. R. (2008). Empresa familiar e as dificuldades enfrentadas pelos membros da terceira geração. Revista de Ciências da Administração, $10(22), 30-54$.

Mattingly, E. S. (2015). Dependent variables in entrepreneurship research. The Journal of Entrepreneurship, 24(2), 223-241.

Mattingly, E. S., \& Kuschev, T. (2016). Most new businesses fail, but mine won't... right? The Journal of Entrepreneurship, 25(1), 70-88.

Mintzberg, H. (2003). Criando organizações eficazes: estruturas em cinco configuraçôes. São Paulo: Editora Atlas.

Manning, P., Stokes, P., Tarba, S. Y., \& Rodgers, P. (2020). Entrepreneurial stories, narratives and reading - Their role in building entrepreneurial being and behaviour. The International Journal of Entrepreneurship and Innovation, 21(3), 178-190. https://doi.org/10.1177/1465750319889234

Moraes, M. J., Hashimoto, M., Albertine, T. Z., \& Sbarini, J. (2012). Análise comparativa do perfil empreendedor entre motoristas autônomos e funcionários no transporte rodoviário de cargas. Revista da Micro e Pequena Empresa, 6(2), 107-124.

Murphy, P., Liao, J., \& Welsch, H. P. (2006). A conceptual history of entrepreneurial thought. Journal of Management History, 12(1), 12-35. 
Muzzio, H. (2012). Racionalidades em jogo em um processo de profissionalização organizacional. Revista Administração Contemporânea, 16(6), 827-844.

Muzzio, H. (2013). A consolidação da profissionalização da empresa familiar e o legado do fundador: concepçóes teóricas e implicaçóes práticas. Teoria e Prática em Administração, 3(2), 27-43.

O'Gorman, C., Bourke, S., \& Murray, J. A. (2005). The nature of managerial work in small growthoriented businesses. Small Business Economics, 25(1), 1-16.

Oliveira, A. G. M., Melo, M. C. O. L., \& Muylder, C. F. (2015). Educação empreendedora: O desenvolvimento do empreendedorismo e inovação social em instituiçôes de ensino superior. Revista Administração em Dialogo, 18(1), 29-56.

Oliveira, M., \& Freitas, H. (1998). Focus Group, pesquisa qualitativa: resgatando a teoria, instrumentalizando o seu planejamento. Revista de Administração da USP, 33(3), 83-91.

Oliveira, V. C., Silva, W. A. C., Araujo, E. A. T., \& Gilson, E. E. (2013). Análise do ciclo de vida organizacional e longevidade de micros e pequenas empresas distribuidoras de gás de petróleo. Teoria e Prática em Administração, 3(2), 1-26.

Pamplona, J. B. (2001). O setor informal. Cadernos PUC, 11, 111-142.

Pasquali, L., \& Alves, A. R. (2004) Validação do Portrait Questionnaire de Schwartz no Brasil. Avaliação Psicológica, 3(2), 73-82.

Peredo, A. M., \& Mclean, M. (2006). Social entrepreneurship: A critical review of the concept. Journal of World Business, 41(1), 56-65.

Procópio, M. L. (2012). Administração e valores: em busca de novos caminhos para a compreensão do comportamento administrativo. Revista Eletrônica de Ciência Administrativa, 11(2), 233-254.

Roche, F. P. (2002). Gestão desportiva: Planejamento estratégico nas organizaçóes desportivas. São Paulo: Editora Artmed.

Rokeach, M. (1968). Beliefs, attitudes and values. San Francisco, CA: Jossey-Bass.

Rokeach, M. (1973). The nature of human values. New York: Free Press.

Rokeach, M. (1981). Crenças, atitudes e valores. Rio de Janeiro: Interciência.

Sa, M. L. L., \& Chai, Y. K. (2020). Managerial orientations and business performance in small and medium tourism accommodation businesses (SMTABs): A resource advantage-knowledge creation approach. The International Journal of Entrepreneurship and Innovation, 21(1), 17-37.

Salamouris, I. S. (2013). How overconfidence influences entrepreneurship. Journal of Innovation and Entrepreneurship, 2(8), 1-6.

Sambiase, M. F., Teixeira, M. L. M., Bilsky, W., Araújo, B. V. B., \& Domenico, S. M. R. (2014). Confrontando estruturas de valores: Um estudo comparativo entre PVQ-40 e PVQ-21. Psicologia, Reflexão e Crítica, 27(4), 728-739.

Schumpeter, J. A. (1934). The theory of economic development. Cambridge, MA: Harvard University Press.

Schwartz, S. H. (1990). Individualism-collectivism: Critique and proposed refinements. Journal of Cross-Cultural Psychology, 58(5), 878-891.

Schwartz, S. H. (1992). Universals in the content and structure of values: Theoretical advances and empirical tests in 20 countries. In M. Zanna (Eds). Advances in experimental social psychology (pp. 1-65). Orlando, FL: Academic Press. 
Schwartz, S. H. (1994). Are there universal aspects in the content and structure of values? Journal of Social Issues, 50(4), 19-45.

Schwartz, S. H. (2006). Há aspectos universais na estrutura e no conteúdo dos valores humanos? In M. Ross, \& V. V. Gouveia (Eds). Psicologia social dos valores humanos: Desenvolvimentos teóricos metodológicos e aplicados (pp. 55-85). São Paulo: Editora Senac.

Schwartz, S. H., Cieciuch, J., Vecchione, M., Davidov, E., Fischer, R., \& Konty, M. (2012). Refining the theory of basic individual values. Journal of Personality and Social Psychology, 103(4), 663-688.

Selltiz, C. (1974). Métodos de pesquisa nas relaçōes sociais. São Paulo: Editoria E.P.U.

Sesen, H., \& Pruett, M. (2014). The impact of education, economy and culture on entrepreneurial motives, barriers and intentions: A comparative study of the United States and Turkey. The Journal of Entrepreneurship, 23(2), 231-261.

Sharma, P., \& Chrisman, J. (1999). Toward a reconciliation of the definitional issues in the field of corporate entrepreneurship. Entrepreneurship Theory and Practice, 23(3), 11-27.

Silva, A. S. (2014). Um modelo de antecedentes para a cocriação de valores em serviços de geriatria na cidade de São Paulo: Uma aplicação da modelagem e equaçôes estruturais. Dissertação de Mestrado, Universidade Municipal de São Caetano do Sul, SP, Brasil. Retrieved from http://repositorio.uscs. edu.br/handle/123456789/469 .

Silva, A. H., \& Fossá, M. I. T. (2014). Rituais corporativos como estratégia de legitimação dos valores organizacionais em empresas familiares. Organizaçôes em contexto, 10(20), 117-144.

Silva, F., Couto, G., \& Coelho, H. (2012). Entrepreneurial potential in the younger generation. Journal of Small Business \& Entrepreneurship, 25(1), 93-102.

Slack, T., \& Parent, M. M. (2006). Understanding sport organizations: the application of organization theory. Champaign, IL: Human Kinetics.

Stevenson, H. H. \& Jarillo, J. C. (1990). A paradigm of entrepreneurship: Entrepreneurial management. Strategic Management Journal, 11(5), 17-27.

Steward, A., \& Hitt, M. (2012). Why can't a family business be more like a nonfamily business? Modes of professionalization in family firms. Family Business Review, 25(1), 58-86.

Tamayo, A., Mendes, A. M., \& Paz, M. G. T. (2000). Inventário de valores organizacionais. Estudos de Psicologia, 39(2), 129-140.

Tamayo, A., \& Porto, J. B. (2009). Validação do Questionário de Perfis de Valores no Brasil. Psicologia: Teoria e Pesquisa, 25(3), 369-376.

Tan, W. L., Williams, J., \& Tan, T. M. (2005). Defining the "social” in "social entrepreneurship": Altruism and entrepreneurship. International Entrepreneurship and Management Journal, 1(3), $353-365$.

Tinoco, J. E. P., Assêncio, E. W., João, B. N., \& Claro, J. A. C. S. (2011). Influência dos valores individuais no desempenho empresarial: Um estudo usando o inventário de valores de Schwartz. Sociedade, Contabilidade e Gestão, 6(2), 139-155.

Tornikoski, E., \& Maalaoui, A. (2019). Critical reflections - The Theory of Planned Behaviour: An interview with Icek Ajzen with implications for entrepreneurship research. International Small Business Journal, 37(5), 536-550.

Trad, L. A. B. (2009). Grupos focais: Conceitos, procedimentos e reflexôes baseadas em experiências com o uso da técnica em pesquisas de saúde. Physis Revista de Saúde Coletiva, 19(3), 777-796. 
Valentin, F., Damásio, B. F. (2016). Variância média extraída e confiabilidade composta: Indicadores de precisão. Psicologia: Teoria e Pesquisa, 32(2), 01-07.

Vale, G. M. V. Corrêa, V. S., \& Reis, R. F. (2014). Motivações para o empreendedorismo: necessidade versus oportunidade? Revista de Administração Contemporânea, 18(3), 311-327.

Verga, E., \& Silva, L. F. S. (2014). Empreendedorismo: Evolução histórica, definições e abordagens. Revista de Empreendedorismo e Gestão de Pequenas Empresas, 3(13), 03-30.

Viana, A. B. N. (2011). Administração de varejo com foco em casos brasileiros. Rio de Janeiro: LTC.

Vignochi, L., Lezana, A. G. R., \& Camilotti, L. (2014). Empreendedorismo e valores humanos: um estudo conceitual. Revista Eletrônica de Gestão Organizacional, 11(2), 271-292.

Vuong, Q. H., Do, T. H., \& Vuong, T. T. (2016). Resources, experience, and perseverance in entrepreneurs' perceived likelihood of success in an emerging economy. Journal of Innovation and Entrepreneurship, 5(18), 1-24.

Wakkee, I., Veen, M. V. D., \& Eurlings, W. (2015). Effective growth paths or SMEs. The Journal of Entrepreneurship, 24(2), 169-185.

Wang, C., Walker, E., \& Redmond, J. (2011). Explaining the lack of strategic planning in SMEs: The importance of owner motivation. Journal of Organisational Behavior, 12(1), 01-16.

Wang, X., \& Jessup, L. M. (2014). A review and synthesis of entrepreneurship research: Towards an integrative model of dependent variables. The Journal of Entrepreneurship, 23(2), 163-199.

Wiklund, J., Wright, M., \& Zahra, S. A. (2019). Conquering relevance: Entrepreneurship research's grand challenge. Entrepreneurship Theory and Practice, 43(3), 419-436.

Williamson, A. J., Battisti, M., Leatherbee, M., \& Gish, J. J. (2019). Rest, zest, and my innovative best: Sleep and mood as drivers of entrepreneurs' innovative behavior. Entrepreneurship Theory and Practice, 43(3), 582-610.

Zuccari, P., \& Belluzzo, R. C. B. (2016). A competência em informação e o perfil empreendedor no âmbito das organizaçóes. Perspectiva em Gestão \& Conhecimento, 6(1), 61-71.

\section{AUTHOR'S CONTRIBUTION}

Author 1: field research

Author 2: conceptual orientation, manuscript review

Author 3: methodology, manuscript review

\section{CONFLICTS OF INTEREST}

The authors states that there are no conflicts of interests 